\title{
Upaya Meringankan Biaya Penerangan Gerobak Kaki Lima Di Saat Pandemi COVID-19 Dengan LED Bertenaga Surya
}

\author{
Mauludi Manfaluthy \\ Jakarta Global University \\ Program Studi Teknik Elektro, Fakultas Teknik dan Ilmu Komputer \\ ${ }^{1}$ mauludi@jgu.ac.id
}

\begin{abstract}
One of the impacts of the COVID 19 pandemic is that the purchasing power of each person has become weak, the economic burden which is quite pressing on the entire community is felt more by food cart traders. Sales hours are also limited, on the other hand, operations must be kept running. Entering the month of Ramadan, the hours of selling are more in the afternoon before breaking the fast until late at night, street cart traders need lighting lights. This is an additional burden that must be borne without being able to compensate for the selling price. We have done community service; we conducted a socialization on the use of LED Lighting which can get a source from solar cells and can be charged like a cellphone. From our observations, it can help traders reduce the burden of electricity costs.
\end{abstract}

Keywords: LED, Cart, Street Vendor, Solar Power

\section{ABSTRAK}

Salah satu dampak pandemic COVID 19 adalah daya beli orang per orang menjadi lemah, beban ekonomi yang cukup menghimpit seluruh masyarakat lebih dirasakan oleh para pedagang gerobak makanan. Jam berjualan juga terbatas, di sisi lain operasional harus tetap berjalan.Memasuki bulan Ramadhan jam berjualan lebih banyak di sore hari menjelang buka puasa sampai dengan malam hari, pedagang gerobak kaki lima memerlukan lampu penerangan digerobaknya. Hal ini menjadi beban tambahan yang harus di tanggung tanpa bisa mengkompensasi dengan harga jual. Pada kesempatan Pengabdian masyarakat, kami melakukan sosialisasi penggunaan Lampu Penerangan LED yang bisa mendapatkan sumber dari sel surya dan dapat di charge layaknya handphone. Dari hasil pengamatan kami, dapat membantu para pedagang mengurangi beban biaya listrik.

Kata kunci: LED, Gerobak, Pedagang Kaki Lima, Tenaga Surya 


\section{PENDAHULUAN}

Kegiatan Pengabdian Kepada Masyarakat ini di dasari oleh fakta-fakta Kasus positif Covid19 di Indonesia terus betambah selama beberapa bulan ini. Oleh karena itu, beberapa pemerintah daerah mengeluarkan kebijakan tentang pembatasan masyarakat berskala besar ataupun berskala kecil. Akibatnya, aturan itu berdampak pada pendapatan sejumlah pelaku usaha tingkatan kecil, khususnya para pedagang kaki lima yang biasa menjajakan jualannya pada malam hari. Adanya aturan jam malam membuat omset pedagang makanan saat malam hari turun drastis. Umumnya para pedagang mulai keluar untuk berjualan sekitar pukul 18.00 WIB hingga 23.00 WIB, ada yang pada lokasi permanen ataupun berkeliling dengan jalan kaki di sejumlah kompleks perumahan dikarenakan saat pandemi orang jarang yang keluar saat malam hari. Omset yang mereka dapatkan per malam, kurang lebih di kisaran Rp.300.000 sebelum pandemi, saat pandemi ini hanya sekitar setengahnya.

Bagi pedagang gerobak kaki lima yang bekerja di malam hari, lampu penerangan merupakan kebutuhan yang paling penting. Untuk memenuhi kebutuhan ini, selama ini mereka terkadang menggunakan lilin, ataupun baterai portable yang harus di isi ulang, ataupun membayar biaya listrik kepada pemberi sumber listrik, toko-toko terdekat ataupun rumah disekitar mereka berdagang. Biasanya biaya ini dibayar per bulan.

Agak sulit bagi pedagang untuk menaikan harga saat pandemic, dan terlebih omset yang berkurang, ditambah juga biaya penerangan listrik yang mereka harus tetap bayarkan. Ini semua membuat beban tersendiri bagi para pedagang.

Salah satu dampak COVID-19 bagi pedagang kaki lima adalah keterbatasan waktu untuk membuka lapaknya. Yang biasanya dari pukul 18.00 sampai dengan pukul 23.00, dibatasi menjadi pukul 18.00 - 20.00. Hal ini sudah tentu berdampak pada pendapatan mereka. Disisi lain dengan adanya pengurangan pendapatan mereka masih tetap harus menanggung biaya listrik untuk penerangan gerobak/roda mereka. Sudah jatuh tertimpa tangga, peribahasa ini lebih tepat dikenakan bagi mereka.

Di masa tanggap darurat seperti ini tentu saja tidak menghilangkan salah satu tugas dosen melaksanakan pengabdian kepada masyarat sebagai salah satu pelaksanaan tridharma perguruan tinggi. Dalam kondisi pandemic COVID-19 agak sulit untuk dapat berkumpul secara tatap muka dengan jumlah yang banyak mengingat program pembatasan Sosial Berskala Besar (PSBB) dan pemberlakuan pembatasan kegiatan masyarakat (PPKM) berbasis mikro. Di sisi lain kewajiban PKM haruslah dilaksanakan oleh universitas dan dosen khususnya, oleh karena itu haruslah ada jalan keluarnya yaitu dengan melaksanakan PKM insidentil seperti yang kami lakukan.

Terinspirasi dengan fakta-fakta di atas, maka kami melaksakan kegiatan PKM ini dengan judul Upaya Meringankan Biaya Penerangan Pedagang Gerobak Kaki Lima Di Saat Pandemi COVID-19 Dengan LED Bertenaga Surya.

Beberapa upaya-upaya yang pernah dilakukan perguruan tinggi dan pemerintah dalam hal penerangan listrik untuk pedagan kaki lima adalah seperti ulasan berikut ini:

Dalam hal penerangan listrik yang diperlukan dalam usaha para pedangan kaki lima, ada beberapa cara untuk mendapatkannya, biasanya ada seorang koordinator yang menyediakan saluran listrik (bisa sampai dengan maksimum 2 lampu penerangan), para pedagang membayarnya per bulan, misal Rp. 50.000-75,000 per bulan. Terkadang ada juga penyedia jaringan listrik yang mengambil dari sumber yang tidak resmi, (curi stroom), istilah ini lebih popular di masyarakat.

Salah satu upaya yang dilakukan oleh PT. Perusahaan Listrik Negara (PLN) adalah menyelenggarakan Stasiun Penyediaan Listrik Umum (SPLU) [1]. Tarif listrik SPLU sebesar Rp. 1600/KWH (untuk wilayah DKI Jakarta, saat ini masih terbatas di Jabodetabek). Tarif ini di klaim 
oleh PLN sebagai harga yang terjangkau untuk pedagang kaki lima, PLN membandingkannya dengan biaya operasional genset. SPLU memiliki daya sebesar 5.500 Volt-Ampere (VA). Kapasitas ini dirasa cukup untuk memenuhi kebutuhan listrik PKL di satu wilayah/cluster. Diperlukan Kerjasama dengan pemerintah daerah, tempat mana saja yang perlu didukung dengan solusi SPLU, dengan demikian pedangan kaki lima yang berjualan dengan gerobak yang tidak berpindah-pindah dapat menggunakan SPLU ini. Solusi SPLU tidak tepat sasaran untuk pedagang gerobak kaki lima yang berkeliling berjulannnya, selain tarif yang mahal buat mereka, secara teknis juga tidak bisa memanfaatkan secara maksimal.

Keuntungan penggunaan SPLU lebih dari sisi keamanan. Jika terjadi gangguan korsleting maka mesin akan memutus aliran listrik secara otomatis. Selain itu diharapkan dapat menekan praktik pencurian listrik di masyarakat.

Beberapa perguruan tinggi telah melakukan penelitian dengan membangun gerobak panel surya.[2]. Pada penelitian ini, atap gerobak di design sedemikan mungkin untuk pemasangan panel surya. Dikala siang hari, gerobak ini dapat menghasilkan listrik akibat sinar matahari yang menerangi panel surya yang ada diatas atap gerobak. Solusi ini dapat menghasilkan listrik yang juga dapat di konversi ke AC (arus bolak-balik) sehingga bisa dimanfaatkan tidak hanya untuk lampu penerangan, namun juga alat memasak yang menggunakan listrik. Solusi gerobak listrik juga tidak menyelesaikan masalah bagi para pedagang gerobak kaki lima, mengingat hargnya yang cukup mahal bagi mereka.

Dari hasil pengamatan kami melalui wawancara dengan pedagang gerobak kaki lima dan dari fakta-fakta tersebut diatas kami dapat menyimpulkan masalah dan solusi atas fakta masalah yang dialami pedagang gerobak kaki lima dan memberikan solusi aktual atas masalah tersebut, khususnya bagi para pedagang gerobak kaki lima yang berkeliling. Adapun inti permasalahannya adalah:

- Biaya listrik, penerangan gerobak untuk berjualan, yg selama ini dibayar per-bulan cukup memberatkan para pedagang khususnya saat pandemic covid-19. Jumlah jam jualan terbatas, namun harga biaya listrik tetap harus dibayarkan per-bulan, dengan pendapatan/pembeli yang juga berkurang.

- Bagaimana membantu pedagang kaki lima/memberikan jalan keluar mengurangi beban/biaya lampu penerangan untuk berjualan.

Tujuan kegiatan PKM Upaya Meringankan Biaya Penerangan Pedagang Gerobak Kaki Lima Di Saat Pandemi COVID-19 Dengan LED Bertenaga Surya adalah:

○ Bagi Mitra:

a. Membantu pedangan kaki lima mengurangi biaya operasional mereka dengan jalan menyediakan dan mengarahkan mereka menggunakan lampu penerangan bertenaga surya.

b. Munculnya Sikap Peduli Lingkungan Menuju Indonesia Bebas Emisi khususnya bagi Para pedagang Kaki Lima

c. Jika Mitra melakukan pengembangan dalam skala yang lebih besar maka, dampak ekonomi akan dapat dirasakan dengan lebih karena dapat menekan pembiayaan kebutuhan listrik.

- Bagi JGU:

a. Sosialisasi Sosialisasi Pemanfaatan Sel Surya Sebagai Sumber Energi Terbarukan Dan Instalasi Panel Surya ini dapat meningkatkan citra JGU di masyarakat umum sebagai Universitas yang peduli terhadap kebutuhan masyarakat kecil khususnya.

b. Salah satu upaya JGU meningkatkan kualitas kehidupan masyarakat serta menjadikan listrik sebagai pendorong kegiatan ekonomi dengan berwawasan lingkungan sehingga mampu menyelaraskan berbagai aspek ekonomi dan sosial. 
- Bagi Tim PKM JGU Teknik Elektro:

a. Keberhasilan dalam membatu pedang gerobak kaki lima melalui lampu Penerangan LED Sel Surya dapat memberikan semangat dan motivasi bagi Tim guna mengembangkan Program Kemitraan Masyarakat dalam aspek yang lebih luas.

b. Tim dapat mengaplikasikan ilmu dan kemampuan yang dimilikinya sebagai bentuk pelayanan kepada masyarakat.

\section{METODE}

Salah satu solusi alternatif untuk menanggulangi permasalahan yang diuraikan di atas adalah dengan menerapkan lampu LED gerobak tenaga surya untuk pedagang keliling/kaki lima. Dimana sistem penerangan pada gerobak tersebut dimodifikasi tidak lagi menggunakan lampu tempel ataupun petromaks tetapi dengan menggunakan sumber tenaga dari matahari. Metode kegiatan ini menggunakan pendekatan survei-eksperimen dan pendampingan agar lebih efektif dan efisien dalam mencapai target luaran. Berikut ini merupakan tahapan pendekatan yang digunakan:

1. Observasi.

Kegiatan observasi dilakukan untuk menganalisis kebutuhan berdasarkan situasi pada pedagang gerobak kaki lima di sekitar kelurahan Jatimelati, kecamatan Pondok Melati, Bekasi. Tujuan observasi ini adalah untuk mengidentifkasi permasalahan. Tim langsung berkunjung ke lokasi, melakukan pengecekan dan dokumentasi serta wawancara dengan mitra.

2. Perencanaan.

Merencanakan solusi yang cocok dengan sistem penerangan lampu jalan bertenaga surya. Perencanaan Solusi dalam rangka menyelesaikan permasalahan yang muncul pada situasi saat ini, khususnya saat pandemic covid-19.

3. Sosialisasi dan Pendampingan.

Rancangan solusi yang diberikan oleh TIM PKM Jurusan T. Elektro Jakarta Global University adalah memperkenalkan penggunaan lampu penerangan LED dengan tenaga surya. Sosialisasi dan pendampingan yang terencana dilakukan oleh tim, dimulai dengan pengenalan hardware dan solar panel. Mitra dibimbing dan didampingi dalam proses pemasangan instalasi, penggunaan dan perawatan jangka panjang. Selain itu sosialisasi juga menekankan tentang pemanfaatan sumber daya alam yang keberadaannya melimpah disekitar kita yaitu mengkonversi cahaya matahari menjadi energi listrik.

4. Serah terima produk.

Serah terima lampu jalan bertenaga surya kepada mitra. Memberikan sosialisasi bagi pedagang gerobak kaki lima dapat membantu mereka dari segi ekonomi.

5. Dokumentasi dan Publikasi.

Dokumentasi proses kegiatan dari awal sampai akhir dilakukan menggunakan kamera secara mandiri Sedangkan laporan akhir dibuat sesuai format standar pengabdian masyarakat dan keluaran lain dalam bentuk jurnal/publikasi.

\section{HASIL DAN PEMBAHASAN}

Tim pelaksana pengabdian kepada Masyarakat Universitas Global Jakarta (JGU) melaksanakan kegiatan pengabdian pada hakikatnya merupakan bentuk dukungan Jakarta Global University dalam mendampingi mitra (pedagang gerobak kaki lima) sebagai upaya membaca permasalahan yang ada dimasyarakat kecil dan memberikan jalan keluarnya menghadapi krisis akibat pandemi Covid-19. Berikut ini foto-foto kegiatan pengabdian kepada masyarakat 


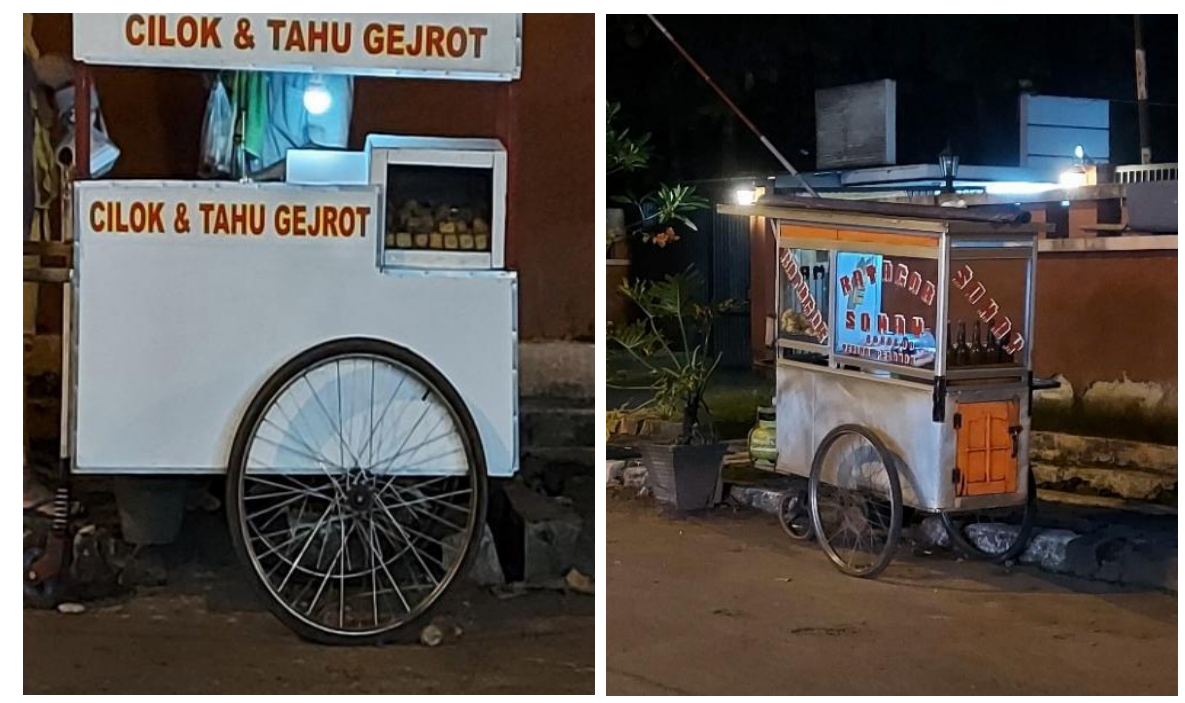

Gambar 1. Gerobak dengan lampu Penerangan LED

Pada gambar 1, gerobak mitra dengan lampu penerngan LED Surya yang sudah terpasang. Lampu daya terpasang 7 watt, di sekitar pukul 20.00.

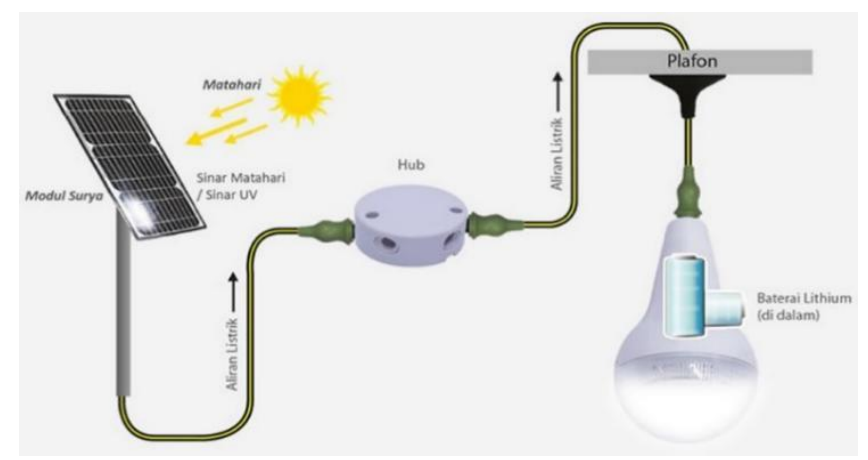

Gambar 2. Skematik Lampu Penerangan LED Tenaga Surya

Gambar 2 adalah skematik [3.4] dari lampu penerangan LED tenaga surya yang menurut evaluasi dan observasi kami adalah cocok digunakan oleh pedagang gerobak kaki lima dari segi teknis dan ekonomis. Kelebihan model lampu LED surya seperti ini adalah menggunakan chip LED SMD 2835 (LED dengan daya maksimal 0.5Watt per buah, ada 20 buah). Selain itu juga rechargeable baik dengan panel surya ataupun charger ponsel. Ini memunkingkan mitra untuk tetap melakukan charge dengan charger ponsel jika sinar matahari tidak bisa didapat. 


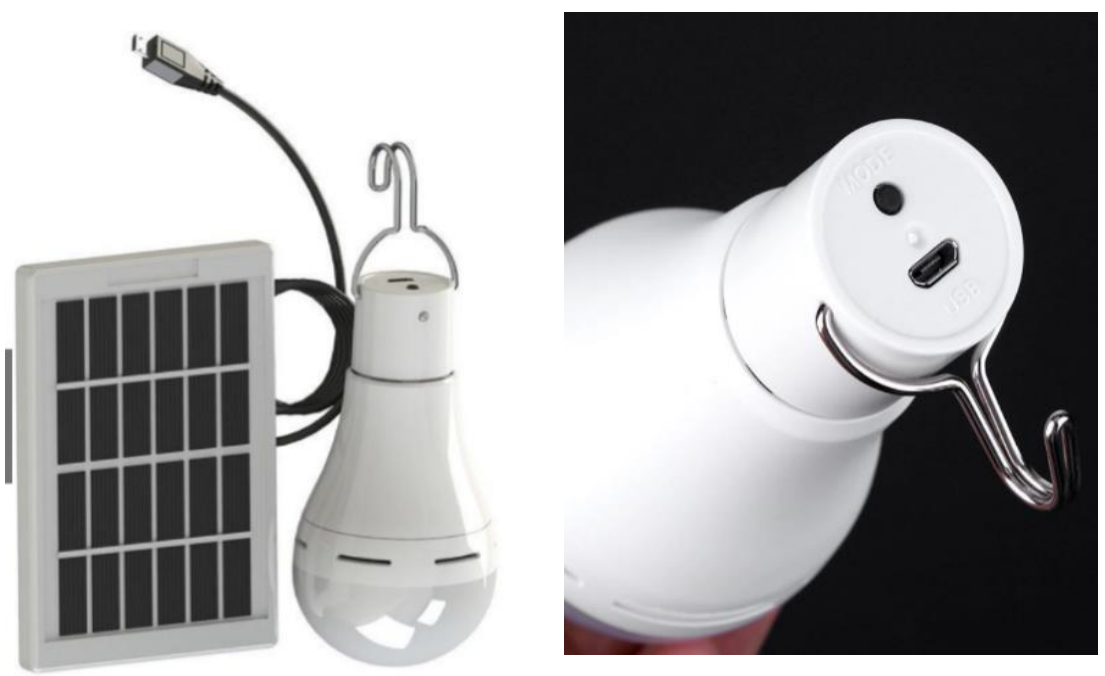

Gambar 3. Lampu Penerangan LED Tenaga Surya

Pada gambar 3 ditunjukan Lampu LED bertenaga surya. Ada tiga komponen penting dalam lampu LED tenaga surya ini adalah panel surya, Lampu LED, dan baterai dengan USB charging (Rechargeable). Selain itu juga dilengkapi dengan switch dan pengait agar dapat mudah di pasang di gerobak. Lampu LED penerangan ini memiliki baterai internal. Didukung oleh panel surya 6V dengan daya $1.2 \mathrm{~W}$ atau pengisi daya ponsel, Port pengisian lampu LED Penerangan adalah port Android, yang merupakan pengisi daya Android universal. Tetapi panel surya tidak dapat mengisi daya ponsel, ini harus diperhatikan, karena tegangan output panel surya $6 \mathrm{~V}$, tegangan input umum ponsel hanya $1,5 \mathrm{~V}$.

Spesifikasi dari lampu penerangan LED bertenaga surya [5] di atas adalah sebagai berikut:

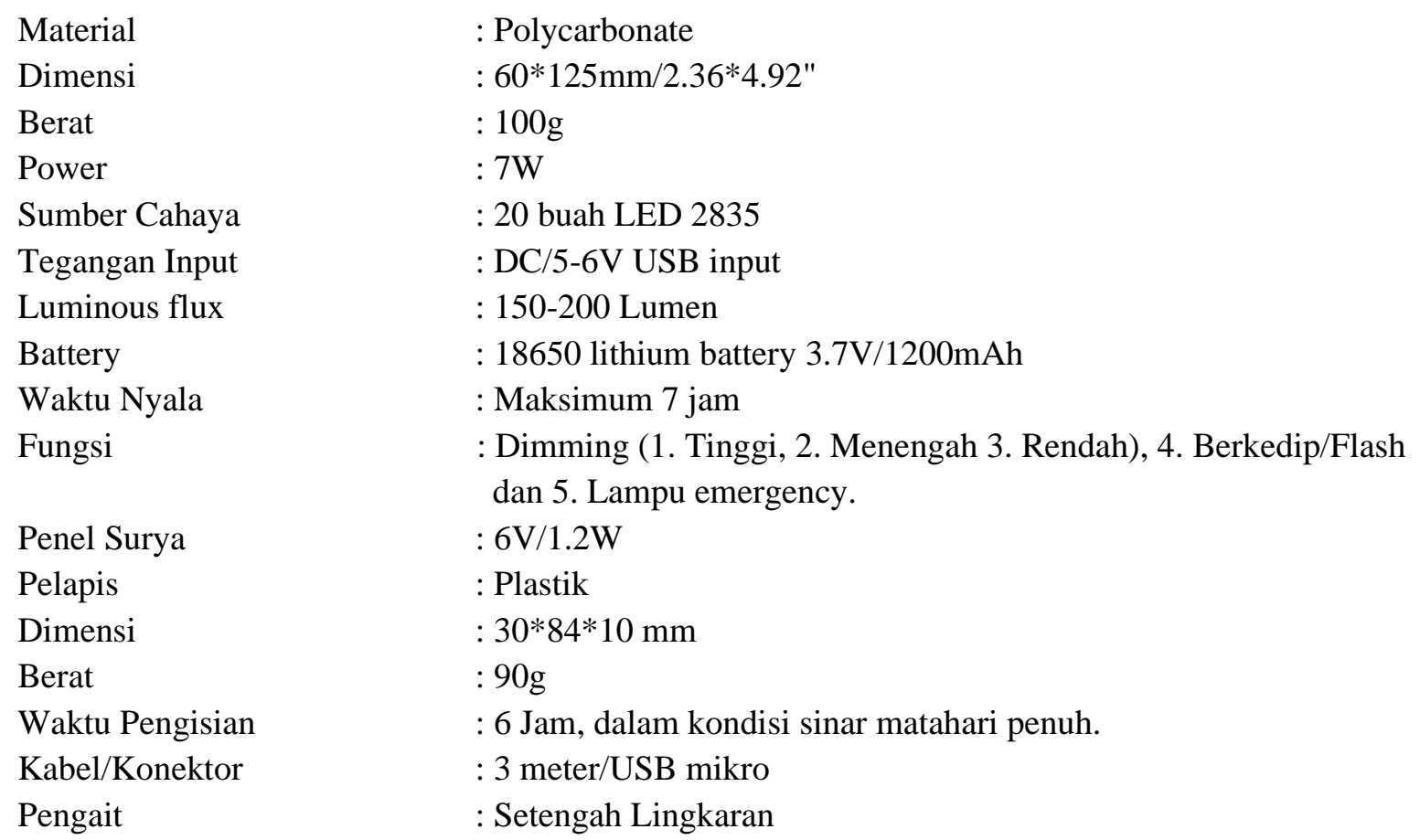



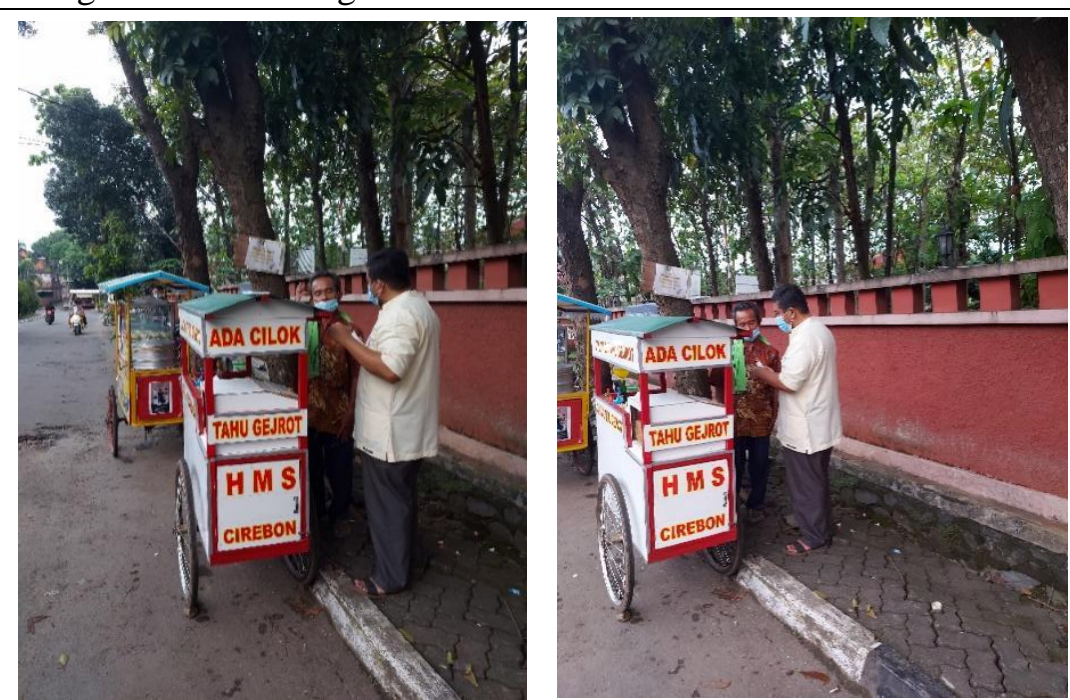

Gambar 4. Foto Sosialisi Lampu Penerangan LED

Sebelum melakukan pemasangan/instalasi, terlebih dahulu diberikan penyuluhan (gambar 4) pada mitra berkenaan dengan kelebihan dari penggunaan lampu LED panel surya, fungsi-fungsi yang bisa digunakan, saran penggunaan dan cara-cara pemasangan.
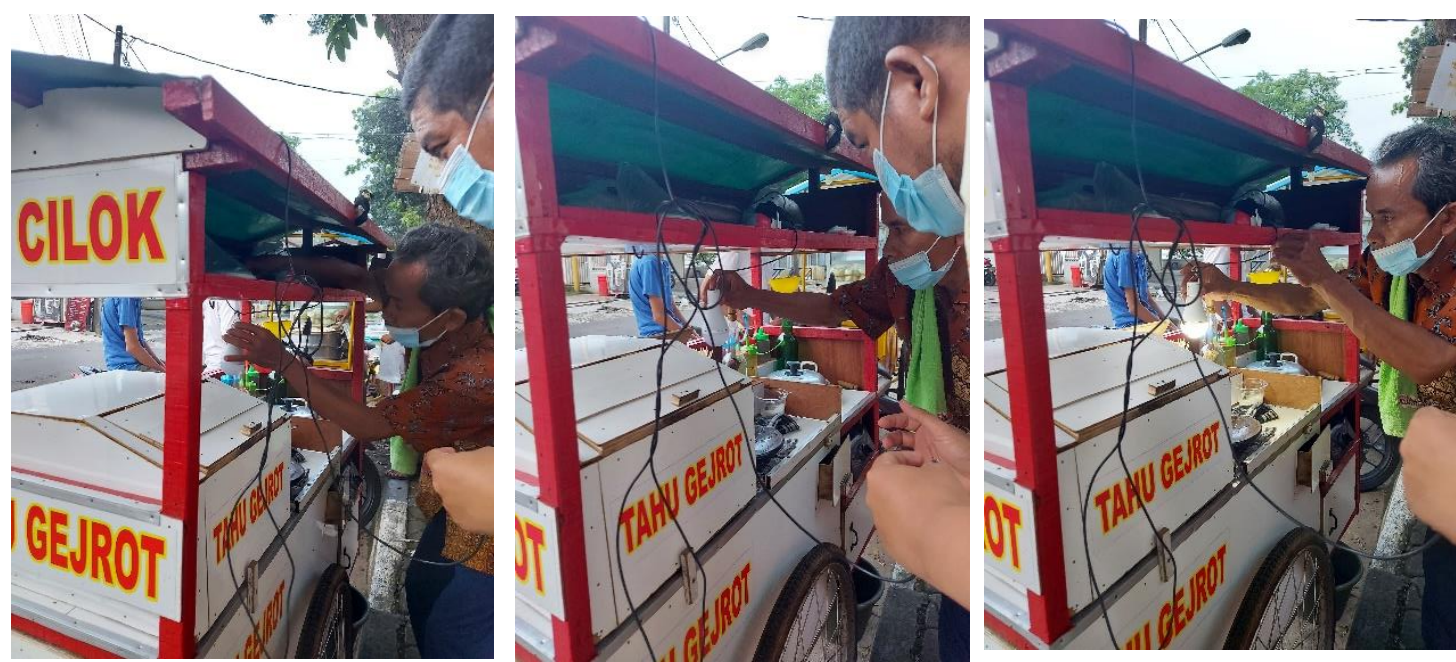

Gambar 5. Foto Instalasi Lampu Penerangan LED

Setelah diberikan penyuluhan dan mitra memahaminya, mitra langsung melakukan pemasangan lampu LED (gambar 5) sendiri di gerobaknya. Dimulai dengan pemasangan panel surya pada atap gerobak, instalasi kabel dan menjalan fungsi-fungsi yang ada pada lampu LED. Semua berjalan lancer dan lampu LED hidup/berjalan baik. 


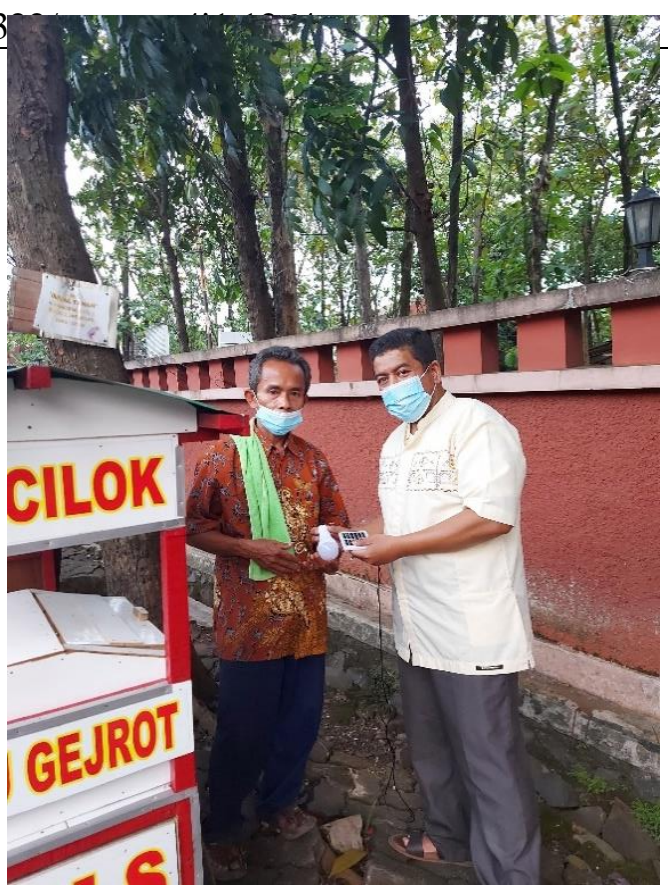

Gambar 6. Penyerahan produk LED Panel Surya

Tabel 1 menunjukan perbandingan beberapa solusi alternatif untuk lampu penerangan gerobak kaki lima disertai biaya serta kelebiha dan kekurangannya.

Tabel 1. Perbandingan Lampu Penerangan Gerobak

\begin{tabular}{|c|c|c|}
\hline $\begin{array}{c}\text { Solusi } \\
\text { Alternatif }\end{array}$ & Estimasi Biaya & Kelebihan/Kekurangan \\
\hline $\begin{array}{c}\text { Gerobak Sel } \\
\text { Surya }\end{array}$ & $\begin{array}{c}\text { Rp. 3.000.000, (Panel surya } \\
\text { dengan daya 20 Watt Peak. }\end{array}$ & $\begin{array}{c}\text { Cukup mahal, aman, tidak cocok untuk pedagang } \\
\text { gerobak keliling kali lima. }\end{array}$ \\
\hline SPLU - PLN & Rp. 1600 per KWH & $\begin{array}{c}\text { Lebih cocok untuk pedagang yang menetap, } \\
\text { dapat digunakan untuk sumber listrik peralatan } \\
\text { lainnya. }\end{array}$ \\
\hline Bayar & $\begin{array}{c}\text { Rp. 50.000-Rp. 75.000 per } \\
\text { bulan untuk 1 titik koneksi } \\
\text { lampu. }\end{array}$ & Ada kemungkinan pencurian lisrik terjadi. \\
\hline $\begin{array}{c}\text { Lampu LED } \\
\text { Sel Surya }\end{array}$ & $\begin{array}{c}\text { Rp. 50.000,- (untuk 1 } \\
\text { Lampu, bisa digunakan } \\
\text { untuk 1 tahun). }\end{array}$ & $\begin{array}{c}\text { Lebih murah, terjangkau, aman. fleksibel dan } \\
\text { ramah lingkungan }\end{array}$ \\
\hline
\end{tabular}

\section{KESIMPULAN}

Kesimpulan yang dapat di ambil dari kegitan Pengabdian Masyarakat dengan judul Upaya Meringankan Biaya Penerangan Pedagang Gerobak Kaki Lima Di Saat Pandemi COVID-19 Dengan LED Bertenaga Surya, adalah:

1. Program kegiatan kemitraan ini membantu pedagang gerobak kaki lima secara ekonomi, dengan mengurangi biaya operasional penerangan ketika mereka berdagang keliling di malam hari.

2. Selain membantu mengurangi beban perekonomian pedagang juga memberikan memberikan pengetahuan tentang pemanfaatan sel surya sebagai sumber energi alternatif yang sangat dekat dengan kehidupan kita setiap harinya. Diharapkan mampu membuka 
wawasan sekaligus memberikan motivasi kepada pihak Mitra untuk melakukan pengembangan pemanfaatannya sebagai bentuk kepedulian kita terhadap masa depan bumi dikemudian hari.

3. Berdasarkan evaluasi yang dilakukan terhadap kegiatan ini menunjukkan bahwa kegiatan ini masih dapat dilanjutkan Kembali/diperluas mengingat masih banyak pedagang gerobak kaki lima yang masih belum disentuh. Serta skala sosialisasinya dapat lebih diperluas guna mendapatkan hasil yang lebih maksimal.

\section{SARAN}

Berdasarkan kendala serta uraian kegiatan diatas, saran yang dapat kami berikan antara lain sebagai berikut:

1. Langkah yang dapat ditempuh guna mengurangi biaya LED panel surya adalah dengan membangun kerjasama dengan pihak produsen panel surya dalam rangka menyukseskan kegiatan sosialisai pemanfaatan sumber energi alternatif ini, sehingga tim pelaksana PKM bisa mendapatkan harga beli LED panel surya yang lebih rendah lagi dibandingkan harga yang sebelumnya.

2. Sebaiknya tim PKM Univesitas melakukan pengembangan dalam skala yang lebih besar secara mandiri agar dampak ekonomi dapat dirasakan dengan lebih karena dapat menekan pembiayaan kebutuhan listrik yang selama ini dibebankan. Salah satu caranya adalah dengan membuat lampu LED Panel Surya bekerja sama dengan produsen lampu LED Panel Surya.

3. Pemilihan lokasi PKM selanjutnya diharapkan benar-benar mempertimbangkan dari sisi kebutuhan pihak Mitra, yaitu Mitra yang benar-benar membutuhkan bantuan tenaga Listrik atau pada daerah-daerah yang belum sepenuhnya di aliri oleh listrik.

\section{UCAPAN TERIMA KASIH}

Penulis mengucapkan terima kasih kepada LPPM dan Jurusan Teknik Elektro Jakarta Global University (JGU) yang telah memberi dukungan/membantu pelaksanaan kegiatan pengabdian pada masyarakat ini.

\section{DAFTAR PUSTAKA}

[1] https://kumparan.com/kumparannews/umkm-dan-pedagang-kaki-lima-bisa-beli-listrik-displu-begini-caranya/full

[2] Krismadinata, 2017, Rancang Bangun Gerobak Tenaga Surya Untuk Pedagang Kaki Lima, Prosiding Seminar Nasional ke I, tahun 2017 Balai Riset dan Standardisasi Industri Samarinda.

[3] Hasyim Asy'ari., 2014, Pemanfaatan Solar dengan PLN sebagai Sumber Energi Listrik Rumah Tinggal. Jurnal Emitor Volume 14.

[4] Heri, J., 2011, Jurnal Ilmiah, Pengujian Sistem Pembangkit Listrik Tenaga Surya Solar Cel Kapasitas 50wp.

[5] Datasheet LED Panel Surya 7Watt, Rechargeable. 